\title{
Microwave Assisted Synthesis of Cobalt Phosphate Nanoparticles and Their Antiproliferation against Human Lung Cancer Cells and Primary Osteoblasts in Vitro
}

\author{
Guoqiang Zhou (Corresponding author) \\ College of Chemistry and Environmental Science \\ Key Laboratory of Medicinal Chemistry and Molecular Diagnosis of Ministry of Education \\ Chemical Biology Key Laboratory of Hebei Province, Hebei University \\ Baoding 071002, China
}

Tel: 86-312-507-9359 E-mail: zhougq1982@sohu.com

Wenying Wang, Guangqi Gu \& Yang Li

College of Chemistry and Environmental Science

Chemical Biology Key Laboratory of Hebei Province, Hebei University

Baoding 071002, China

Tel: 86-312-507-9795

Ying Liu

CAS Key Laboratory for Biological Effects of Nanomaterials and Nanosafety

National Center for Nanoscience and Technology

Beijing 100190, China

Received: June 16, 2011

doi:10.5539/ijc.v3n4p127
Accepted: July 7, $2011 \quad$ Published: December 1, 2011

URL: http://dx.doi.org/10.5539/ijc.v3n4p127

This research was financially supported by the National Natural Science Foundation of China (Grant No. 21001038).

\begin{abstract}
In this research, different nanostructures of cobalt phosphate nanoparticles were successfully prepared. Platelike and spherical cobalt phosphate were made by microwave synthesis method without any use of capping agent as structure directors. The reaction was completed under two different microwave irradiation power $(500 \mathrm{~W}$ and $800 \mathrm{~W}$ ) and times $(5 \mathrm{~min}$ and $10 \mathrm{~min}$ ) for the production of two types of cobalt phosphate nanoparticles. The synthesized nanoparticles were characterized by field emission scanning electron microscopy (FE-SEM), powder X-ray diffraction (XRD), BET, fourier transform infrared spectroscopy (FTIR) and dynamic light scattering (DLS). The SEM images showed that the flowerlike nanostructure was an arrangement of cobalt phosphate plates with thickness of $80 \mathrm{~nm}$ and the average size of spherical cobalt phosphate nanoparticles was about $40 \mathrm{~nm}$. Antiproliferation activity of cobalt phosphate nanoparticles as a function of particle concentration against human lung cancer cells and primary osteoblasts were carried out in vitro. The spherical nanoparticles showed better antiproliferation activity than the platelike nanoparticles and primary osteoblasts were more sensitive than human lung cancer cells to cobalt phosphate nanoparticles.
\end{abstract}

Keywords: Cobalt phosphate nanoparticles, Microwave synthesis, Antiproliferation, Osteoblasts

\section{Introduction}

Nanomaterials are defined by the U.S. National Nanotechnology Initiative as materials that have at least one dimension in the 1- to $100-\mathrm{nm}$ range (Stix G, 2001). Due to their unique physicochemical properties such as a 
large specific surface area and greater reactivity, nanotechnology has become one of the leading technologies. The enhanced production and applications of manufactured nanoparticles have raised questions concerning their potential toxicological effects (Oberdorster G, 2005). Cobalt phosphate $\left(\mathrm{Co}_{3}\left(\mathrm{PO}_{4}\right)_{2}\right)$ was introduced as violet pigment by Salve'tat in 1895. It's hue fluctuate between pink and violet because of state of hydration (Dalia J, 2009). $\mathrm{Co}_{3}\left(\mathrm{PO}_{4}\right)_{2}$ can be used as catalyst, for example, amorphous $\mathrm{Co}_{3}\left(\mathrm{PO}_{4}\right)_{2}$ can be used as catalyst in the oxidation of water in the presence of sun light and for the selective reduction of $\mathrm{NO}$ with $\mathrm{C}_{3} \mathrm{H}_{6}$ or $\mathrm{CH}_{4}$ (Matthew W K, 2009). $\mathrm{Co}_{3}\left(\mathrm{PO}_{4}\right)_{2}$ and it's derivatives especially $\mathrm{LiCoPO}_{4}$ are taken into account as candidates which can be used as cathodes in lithiumion batteries (Jang I C, 2010).

Usage of nanostructures of $\mathrm{Co}_{3}\left(\mathrm{PO}_{4}\right)_{2}$ is a key to improve its applications. As materials dimensions approach the nanoscale, certain properties become scale dependent. These include optical color, conductivity, electron affinity and catalytic activity (Clinton F J, 2009). So $\mathrm{Co}_{3}\left(\mathrm{PO}_{4}\right)_{2}$ which has proper nanostructure can perform significantly better in battery cathodes usage and catalytic applications (Lee M T, 2009). Recently, it has been reported that microware irradiation can be used to prepare high purity nanoparticles with narrow particle size distributions. Microwave heating has been known since the early 1940s, and has been used in preparative chemistry and material synthesis since 1986 (Giguere R J, 1986). Microwave irradiation is an efficient and distinct heating method, and has attracted researcher's interest owing to its unique features such as short reaction time, rapid volumetric heating, energy saving and high reaction rate (Ela S E, 2009). The greatest advantage of microwave irradiation is that it can heat a substance uniformly through a glass or plastic reaction container, leading to a more homogeneous nucleation and a shorter crystallization time compared with those for conventional heating (Norihito K, 2010). This is beneficial to the formation of uniform colloidal materials.

In this study, $\mathrm{Co}_{3}\left(\mathrm{PO}_{4}\right)_{2}$ nanoparticles with different nanostructures were synthesizd by microwave irradiation process. And the synthesized $\mathrm{Co}_{3}\left(\mathrm{PO}_{4}\right)_{2}$ nanoparticles were characterized by field emission scanning electron microscopy (FE-SEM), powder X-ray diffraction (XRD), BET, fourier transform infrared spectroscopy (FTIR) and dynamic light scattering (DLS). The antiproliferation effects of two types of $\mathrm{Co}_{3}\left(\mathrm{PO}_{4}\right)_{2}$ nanoparticles on human pulmonary adenocarcinoma cells A549 and primary osteoblasts (OBs) were investigated. The results indicated that the $\mathrm{Co}_{3}\left(\mathrm{PO}_{4}\right)_{2}$ nanoparticles inhibited the proliferation of two type cells following dose and time dependent manner. The spherical nanoparticles showed better antiproliferation activity than the platelike nanoparticles and OBs were more sensitive than $\mathrm{A} 549$ cells to $\mathrm{Co}_{3}\left(\mathrm{PO}_{4}\right)_{2}$ nanoparticles.

\section{Experimental}

\subsection{Materials and reagents}

All the chemicals used in this investigation were analytical grade materials and used without further purification. Cobalt sulfate heptahydrate $\left(\mathrm{CoSO}_{4} \cdot 7 \mathrm{H}_{2} \mathrm{O}, \geq 99 \%\right)$, sodium dodecylbenzene sulfonate (SDBS, $\mathrm{C}_{18} \mathrm{H}_{29} \mathrm{NaSO}_{3}$, $99 \%$ ), sodium phosphate monobasic dihydrate $\left(\mathrm{NaH}_{2} \mathrm{PO}_{4} \cdot 2 \mathrm{H}_{2} \mathrm{O}, \geq 99.0 \%\right)$ and urea $\left(\mathrm{CON}_{2} \mathrm{H}_{4}, \geq 98 \%\right)$ were purchased from Sigma Aldrich. Human pulmonary adenocarcinoma cells A549 were purchased from the ATCC (Beijing, Zhongyuan LTD, China). Kunming (KM) mice were obtained from Experimental Animal Center of Hebei Medical University. Dulbecco's modified Eagle's medium (DMEM), RPMI 1640 and trypsin were puchased from GIBCO, USA. New born calf serum was from Hangzhou Sijiqing Organism Engineering Institute. MTT (3-(4,5-Dimethylthi-azol-2-yl)-2,5-diphenyltetrazolium bromide), penicillin, streptomycin, collagenase type II were from Sigma Aldrich. Deionized water was used to prepare aqueous solutions.

\subsection{Synthesis of $\mathrm{Co}_{3}\left(\mathrm{PO}_{4}\right)_{2}$ nanoparticles}

The $\mathrm{Co}_{3}\left(\mathrm{PO}_{4}\right)_{2}$ nanoparticles were synthesized using microwave method. $100 \mathrm{ml}$ of $3 \mathrm{mM} \mathrm{CoSO} \cdot 7 \mathrm{H}_{2} \mathrm{O}, 3 \mathrm{mM}$ $\mathrm{NaH}_{2} \mathrm{PO}_{4} \cdot 2 \mathrm{H}_{2} \mathrm{O}, 0.3 \mathrm{mg}$ of $\mathrm{C}_{18} \mathrm{H}_{29} \mathrm{NaSO}_{3}$ and $6 \mathrm{mg} \mathrm{CON} \mathrm{CH}_{4}$ were mixed in a beaker to get an aqueous solution. This solution was divided in two parts and processed according to different steps respectively. One part of the solution was stirred vigorously for $3 \mathrm{~min}$ and then heated in a microwave oven (Galanz $800 \mathrm{~W}$ ) at $500 \mathrm{~W}$ power for $3 \mathrm{~min}$. After boiling the mixture, the device power was adjust to $200 \mathrm{~W}$ and continue heating $2 \mathrm{~min}$. The other part was stirred vigorously for $3 \mathrm{~min}$ and then heated in a microwave oven at $800 \mathrm{~W}$ power for $10 \mathrm{~min}$. Then the reactor device was taken out and cooled with water. The precipitate was separated by centrifugation (3000 rpm, $5 \mathrm{~min}$ ) and washed with ethanol 5 times. The wet precipitate was maintained at $100{ }^{\circ} \mathrm{C}$ in a laboratory oven for $1 \mathrm{~h}$.

\subsection{Characterization}

The morphology and size of synthesized $\mathrm{Co}_{3}\left(\mathrm{PO}_{4}\right)_{2}$ nanoparticles were measured by field emission scanning electron microscope (JSM-7500F, JEOL, Japan). A minute drop of nanoparticles solution was cast on to a carbon-coated copper grid and subsequently drying in air before transferring it to the microscope. X-ray powder 
diffraction was performed on a Bruker D8 Advance X-ray diffractometer employing $\mathrm{Cu}-\mathrm{K} \alpha$ radiation with $40 \mathrm{kV}$ and $50 \mathrm{~mA}$ (D8 ADVACE, Bruker, Germany). For surface area measurements, the Branauer, Emmett and Teller (BET) method was used with TriStar II 3020, a volumetric adsorption apparatus (TriStar II 3020, Micromiritics, USA).The typical bonds were detected by fourier transform infrared spectroscopy (Nicolet380, Thermo, USA). The FTIR spectra obtained using the improved $\mathrm{KBr}$ pellet method by grinding down the resin beads prior to recording. The size distribution of the nanoparticles in medium was evaluated by dynamic light scattering (Delsa Nano C, Beckman, USA). Data were analyzed based on six replicated tests.

\subsection{Cell culture}

Human lung alveolar carcinoma epithelial cells (A549) were cultured in RPMI 1640 under a humidified atmosphere $\left(5 \% \mathrm{CO}_{2}\right.$ plus $95 \%$ air) at $37{ }^{\circ} \mathrm{C}$. All media were supplemented with $10 \%$ heat inactivated new born calf serum, 100 units $/ \mathrm{ml}$ penicillin, and $100 \mu \mathrm{g} / \mathrm{ml}$ streptomycin. The isolation and culture of OBs were following the method previously described (Zhang J C, 2010).

\subsection{Cell proliferation assay}

A549 Cells and OBs $\left(2 \times 10^{3}\right.$ cells $\left./ 100 \mu \mathrm{l}\right)$ were seeded onto 96 -well plates and incubated overnight at $37{ }^{\circ} \mathrm{C}$ under a $5 \% \mathrm{CO}_{2}$ atmosphere. The medium in the wells was then replaced with fresh medium containing nanoparticles $(5-80 \mu \mathrm{g} / \mathrm{ml})$ and incubation continued for 24 and $48 \mathrm{~h}$. The effects of the nanoparticles on cell viability were determined using the MTT assay. Briefly, $10 \mu \mathrm{l}$ of MTT solution was added to each well and the plates incubated for $4 \mathrm{~h}$. The supernatant was removed and DMSO $(100 \mu \mathrm{l})$ was added to solubilize the MTT. The absorbance at $570 \mathrm{~nm}$ of each well was measured with a microplate spectrophotometer (BioRad Model 3550, USA). Cells incubated without nanoparticles were used as a control. The cell viability was calculated according to the formula: $\mathrm{A}_{\text {sample }} / \mathrm{A}_{\text {control }} \times 100 \%$.

\section{Results and discussion}

\subsection{Morphology characterization}

Two types of $\mathrm{Co}_{3}\left(\mathrm{PO}_{4}\right)_{2}$ nanoparticles were successfully synthesized using microwave irradiation method. The morphology and size of synthesized $\mathrm{Co}_{3}\left(\mathrm{PO}_{4}\right)_{2}$ nanoparticles were examined by field emission scanning electron microscopy (FE-SEM). The results showed that morphology and size of nanoparticles varied with different radiation power and time. Fig. 1B is the local magnified panel of Fig. 1A and shows the typical images of the platelike samples. The $\mathrm{Co}_{3}\left(\mathrm{PO}_{4}\right)_{2}$ plates with thickness of $80 \mathrm{~nm}$ were connected with each other forming 3D nanoflowers (Fig. 1C). When the microwave power reached $800 \mathrm{~W}$ and reaction time extended to 10 min, the stable and nearly spherical nanoparticles with average diameter of $40 \mathrm{~nm}$ were synthesized (Fig. 2). It seems that when the microwave radiation power and reaction time increase, the size of synthesized nanoparticles becomes smaller.

\subsection{XRD analysis}

The phase composition and structure of obtained samples were examined by X-ray powder diffraction (XRD). Fig. 3A and $\mathrm{B}$ showed the XRD patterns of platelike and spherical $\mathrm{Co}_{3}\left(\mathrm{PO}_{4}\right)_{2}$ nanoparticles, respectively. All of diffraction peaks could be indexed to pure monoclinic phase of $\mathrm{Co}_{3}\left(\mathrm{PO}_{4}\right)_{2}$ with lattice constants $\mathrm{a}=7.557 \AA$, $\mathrm{b}=$ $8.365 \AA$ and $\mathrm{c}=5.067 \AA$ (JCPDS Card No. 13-0503). However, the diffraction peaks obtained from platelike nanoparticles were slightly sharper than the diffraction peaks obtained from spherical nanoparticles. According to Scherrer equation, it is clearly indicated that the product crystallinity improved and particle size increased with the decreasing of microwave power and reaction time. These results are consistent with SEM observations. No other impurities can be detected.

\subsection{BET and FTIR analysis}

The BET surface areas for platelike and spherical $\mathrm{Co}_{3}\left(\mathrm{PO}_{4}\right)_{2}$ nanoparticles were 4.15 and $5.25 \mathrm{~m}^{2} / \mathrm{g}$, respectively, which suggest that the smaller sized particles have larger surface areas. The FTIR spectra of the synthesized $\mathrm{Co}_{3}\left(\mathrm{PO}_{4}\right)_{2}$ featured phosphate absorption bands (Fig.4). The triply degenerated asymmetric stretching and bending vibrations of $\mathrm{PO}_{4}^{3-}$ were at 1030 and $570 \mathrm{~cm}^{-1}$. The peaks at $3000 \sim 3500$ and $1627 \mathrm{~cm}^{-1}$ corresponded to the remaining water. The Co-O peaks were at 854 and $703 \mathrm{~cm}^{-1}$.

\subsection{Size distribution in medium}

The SEM images provided information on the size and shape of nanoparticles, however, it could not provide information on whether the nanoparticles existed in single or aggregated forms in the test medium, as the nanoparticles form aggregates when dried on the microscopic observation slide. The size distribution in the test medium, therefore, was investigated using a DLS method, which showed that the average size of platelike and 
spherical $\mathrm{Co}_{3}\left(\mathrm{PO}_{4}\right)_{2}$ in the test medium were $336.3 \pm 52.2 \mathrm{~nm}$ and $132.1 \pm 37.4 \mathrm{~nm}$, respectively (Fig. 5). This suggested that the nanoparticles exposed to the cells did not exist as single particles, but tended to aggregate in the test medium.

\subsection{Effects of $\mathrm{CO}_{3}\left(\mathrm{PO}_{4}\right)_{2}$ nanoparticles on proliferation of cell lines}

Human lung alveolar carcinoma epithelial cells A549 and OBs were continuously treated with two types of $\mathrm{Co}_{3}\left(\mathrm{PO}_{4}\right)_{2}$ nanoparticles for 24 or $48 \mathrm{~h}$ at concentration range from 5 to $80 \mu \mathrm{g} / \mathrm{ml} . \mathrm{Co}_{3}\left(\mathrm{PO}_{4}\right)_{2}$ nanoparticles inhibited the proliferation of two cell lines following dose and time dependent manner. Similar growth inhibition pattern was observed in A549 cells and OBs. For the total range of concentrations, the most pronounced inhibition was found at $48 \mathrm{~h}(p<0.01)$. None of $\mathrm{Co}_{3}\left(\mathrm{PO}_{4}\right)_{2}$ concentrations induced $50 \%$ growth inhibition towards A549 cells at $24 \mathrm{~h}$. But at a concentration of $80 \mu \mathrm{g} / \mathrm{ml} \mathrm{Co}_{3}\left(\mathrm{PO}_{4}\right)_{2}$ induced an inhibition of $60 \%$ in OBs during $24 \mathrm{~h}$ (Fig. $7 \mathrm{~A}$ ). It seems that $\mathrm{OBs}$ are more sensitive than $\mathrm{A} 549$ cells to $\mathrm{Co}_{3}\left(\mathrm{PO}_{4}\right)_{2}$ nanoparticles. The zone of inhibition studied in the two types of $\mathrm{Co}_{3}\left(\mathrm{PO}_{4}\right)_{2}$ nanoparticles synthesized were significantly different as shown in Fig. 6 and Fig. 7. For both cells, the inhibitory effects of spherical nanoparticles were higher than the platelike nanoparticles. We know that the size of spherical $\mathrm{Co}_{3}\left(\mathrm{PO}_{4}\right)_{2}$ is smaller than the platelike $\mathrm{Co}_{3}\left(\mathrm{PO}_{4}\right)_{2}$. It is logical to state that the inhibition of $\mathrm{Co}_{3}\left(\mathrm{PO}_{4}\right)_{2}$ nanoparticles to the cells depends on the particle size. The smaller sized particles which have larger surface areas available for interactions with cells than the larger sized particles, hence they show higher cytotoxicity to cells.

\section{Conclusions}

In summary, platelike and spherical $\mathrm{Co}_{3}\left(\mathrm{PO}_{4}\right)_{2}$ nanoparticles were synthesized successfully using microwave irradiation technique. $\mathrm{Co}_{3}\left(\mathrm{PO}_{4}\right)_{2}$ nanoparticles with average diameter $\sim 80 \mathrm{~nm}$ for $500 \mathrm{~W}$ and $\sim 40 \mathrm{~nm}$ for $800 \mathrm{~W}$ were highly stable as they retained their pink and violet color for a longer duration. SEM images showed that microwave power and reaction time play an important role in the formation of the $\mathrm{Co}_{3}\left(\mathrm{PO}_{4}\right)_{2}$ nanoparticles. In the process of $\mathrm{Co}_{3}\left(\mathrm{PO}_{4}\right)_{2}$ crystal growth, stirring, power, time and its physicochemical nature were responsible for the formation of structures. XRD pattern showed that pure nanostructures with high crystallinity had been made. Antiproliferation activity of $\mathrm{Co}_{3}\left(\mathrm{PO}_{4}\right)_{2}$ nanoparticles revealed that the zone of inhibition was significantly different in case of two types of $\mathrm{Co}_{3}\left(\mathrm{PO}_{4}\right)_{2}$ nanoparticles, while the smaller size nanoparticles showed slightly better antiproliferation effect. In our study, $\mathrm{Co}_{3}\left(\mathrm{PO}_{4}\right)_{2}$ nanoparticles can inhibit the proliferation of A549 cells and OBs following dose and time dependent manner and OBs showed more sensitivity than A549 cells to $\mathrm{Co}_{3}\left(\mathrm{PO}_{4}\right)_{2}$ nanoparticles.

\section{References}

Clinton, F J., \& David, W G. (2009). In vitro assessments of nanomaterial toxicity. Advanced Drug Delivery Reviews, 61, 438-456. http://dx.doi.org/10.1016/j.addr.2009.03.005

Ela, S E., Cogal, S., \& Icli, S. (2009). Conventional and microwave-assisted synthesis of $\mathrm{ZnO}$ nanorods and effects of PEG400 as a surfactant on the morphology. Inorg Chim Acta, 362, 1855-1858. http://dx.doi.org/10.1016/j.ica.2008.08.038

Giguere, R J., Bray, T L., Duncan, S M., \& Majetich, G. (1986). Application of commercial microwave ovens to organic synthesis. Tetrahedron Lett, 27, 4945-4958, http://dx.doi.org/10.1016/S0040-4039(00)85103-5

Jonynaite, D., Senvaitiene, J., Kiuberis, J., Kareiva, A., \& Kareiva, A. (2009). XRD characterization of cobalt-based historical pigments and glazes. Chemija, 20, 10-18.

Jang, I C., Lim, H H., Lee, S B., Karthikeyan, K., Aravindan, V., Kang, K S., Yoon, W S., Cho, W I., \& Lee, Y S. (2010). Preparation of $\mathrm{LiCoPO}_{4}$ and $\mathrm{LiFePO}_{4}$ coated $\mathrm{LiCoPO}_{4}$ materials with improved battery performance. Journal of Alloys and Compounds, 497, 321-324. http://dx.doi.org/10.1016/j.jallcom.2010.03.055

Kijima, N., Yoshinaga, M., Awaka, J., \& Akimoto, J. (2011). Microwave synthesis, characterization, and electrochemical properties of $\alpha-\mathrm{Fe}_{2} \mathrm{O}_{3}$ nanoparticles. Solid State Ionics, 192, 293-297. http://dx.doi.org/10.1016/ j.ssi.2010.07.012

Lee, M T., Hwang, D J., Greif, R., \& Grigoropoulos, C P. (2009). Nanocatalyst fabrication and the production of hydrogen by using photon energy. Int J Hydrogen Energy, 34, 1835-1843. http://dx.doi.org/10.1016/ j.ijhydene.2008.12.022

Matthew, W K., Yogesh S., \& Daniel G N. (2009). Cobalt-phosphate oxygen-evolving compound. Chem Soc Rev, 38, 109-114. http://dx.doi.org/10.1039/B802885K

Nishimori, S., Tanaka, Y., Chiba, T., Fujii, M., Imamura, T., Miyazono, K., Ogasawara,T., Kawaguchi, H., Igarashi, T., Fujita, T., Tanaka, K., \& Toyoshima, H. (2001). Smad-mediated transcription is required for 
transforming growth factor- $\beta 1$-induced p57Kip2 proteolysis in osteoblastic cells. $J$ Biol Chem, 276, 10700-10705. http://dx.doi.org/10.1074/jbc.M007499200

Oberdorster, G., Oberdorster, E., \& Oberdorster, J. (2005). Nanotoxicology: An emerging discipline evolving from studies of ultrafine particles. Environ Health Perspect., 113, 823-839. http://dx.doi.org/10.1289/ehp.7339

Stix, G. (2001). Little big science Nanotechnology. Sci Am, 285, 32-37. http://dx.doi.org/10.1038/scientificamerican0901-32

Zhang, J C., Shang, M Q., Zhang, D W., Li, Y P., Sun, J., \& Chen H. (2010). Effects of $\mathrm{Nd}^{3+}$ and $\mathrm{Sm}^{3+}$ on the proliferation, differentiation and mineralization function of primary osteoblasts in vitro. Chinese Sci Bull, 23, 2505-2511. http://dx.doi.org/10.1007/s11434-010-3153-0
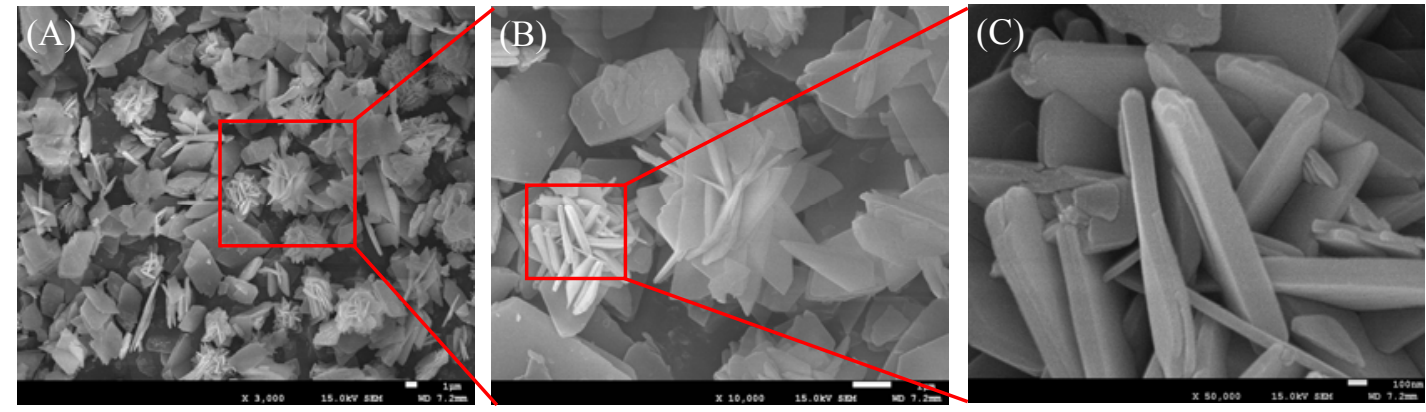

Figure 1. Field emission scanning electron microscope (FE-SEM) images with different magnifications (A-C) of the platelike $\mathrm{Co}_{3}\left(\mathrm{PO}_{4}\right)_{2}$ nanoparticles
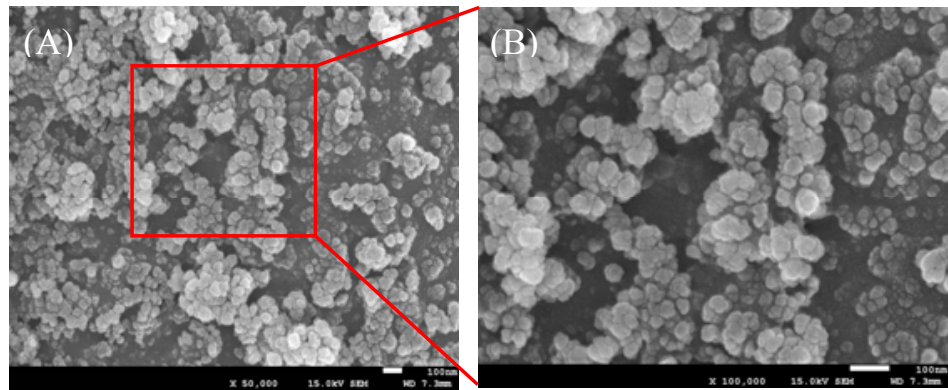

Figure 2. Field emission scanning electron microscope (FE-SEM) images with different magnifications (A-B) of the spherical $\mathrm{Co}_{3}\left(\mathrm{PO}_{4}\right)_{2}$ nanoparticles
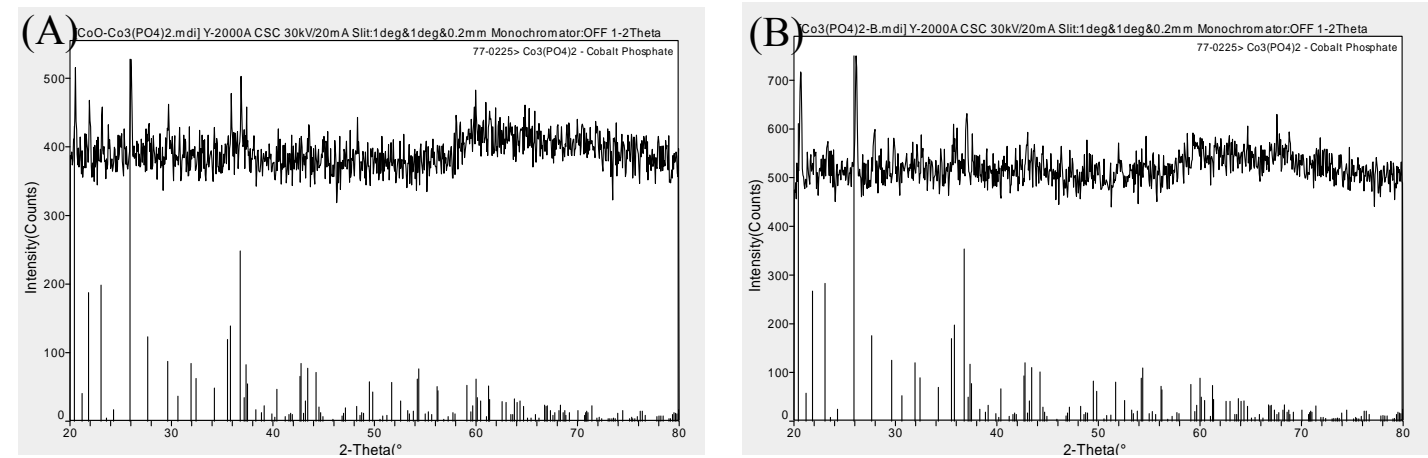

Figure 3. XRD patterns of two types of $\mathrm{Co}_{3}\left(\mathrm{PO}_{4}\right)_{2}$ nanoparticles formed by microwave heating

(A) The platelike $\mathrm{Co}_{3}\left(\mathrm{PO}_{4}\right)_{2}$ nanoparticles; (B) The spherical $\mathrm{Co}_{3}\left(\mathrm{PO}_{4}\right)_{2}$ nanoparticles 

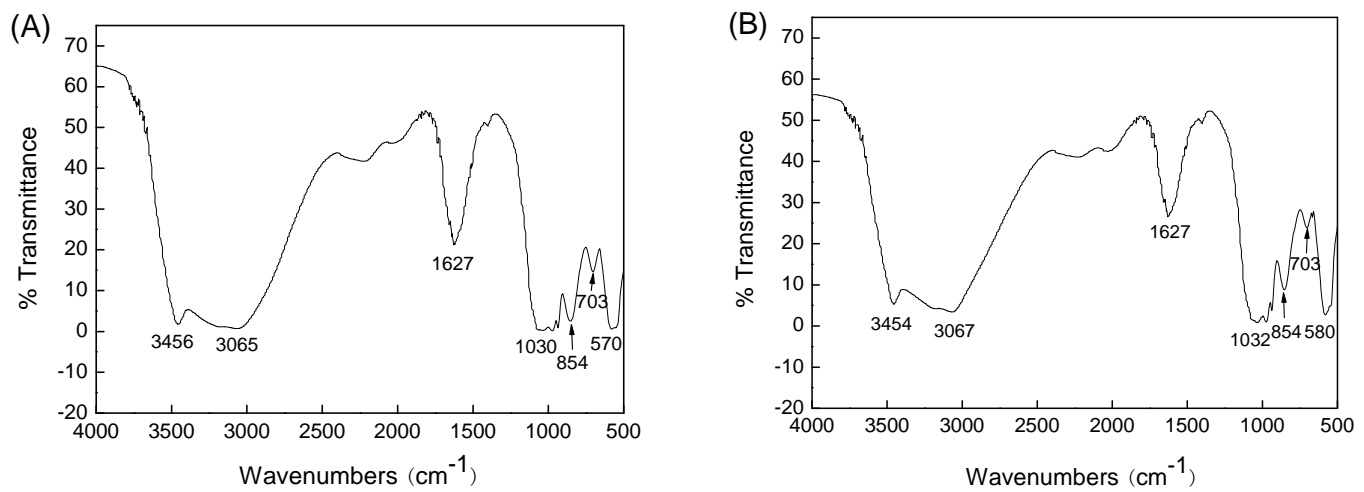

Figure 4. FTIR spectra of samples formed by microwave synthesis method (A) The platelike $\mathrm{Co}_{3}\left(\mathrm{PO}_{4}\right)_{2}$ nanoparticles; (B) The spherical $\mathrm{Co}_{3}\left(\mathrm{PO}_{4}\right)_{2}$ nanoparticles
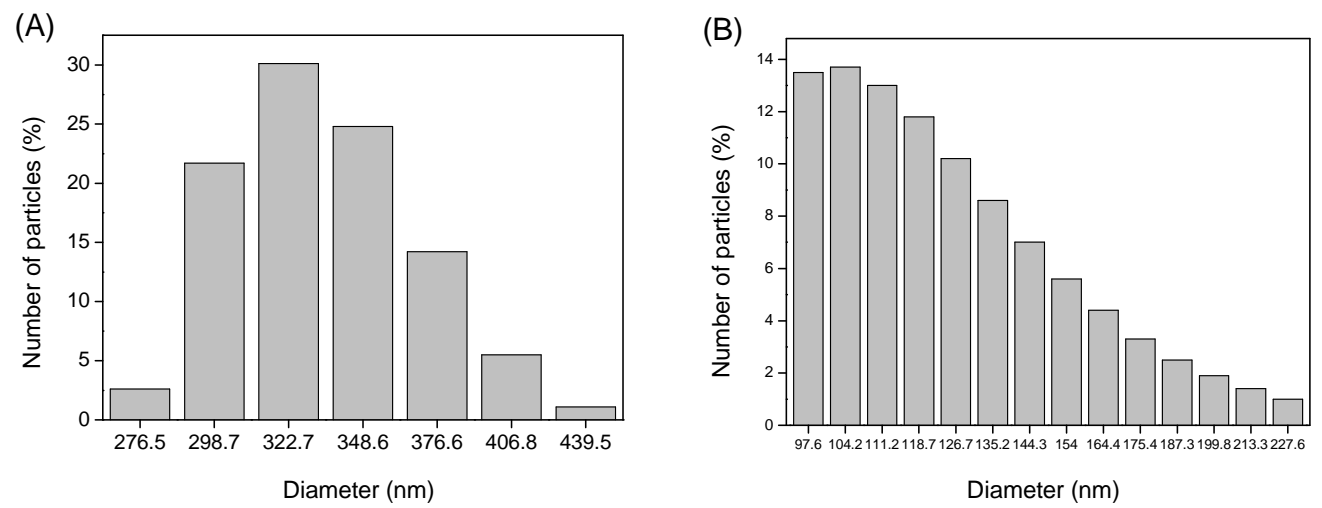

Figure 5. Size distribution of $\mathrm{Co}_{3}\left(\mathrm{PO}_{4}\right)_{2}$ nanoparticles in medium as measured by dynamic light scattering (DLS)

(A) The platelike $\mathrm{Co}_{3}\left(\mathrm{PO}_{4}\right)_{2}$ nanoparticles; (B) The spherical $\mathrm{Co}_{3}\left(\mathrm{PO}_{4}\right)_{2}$ nanoparticles
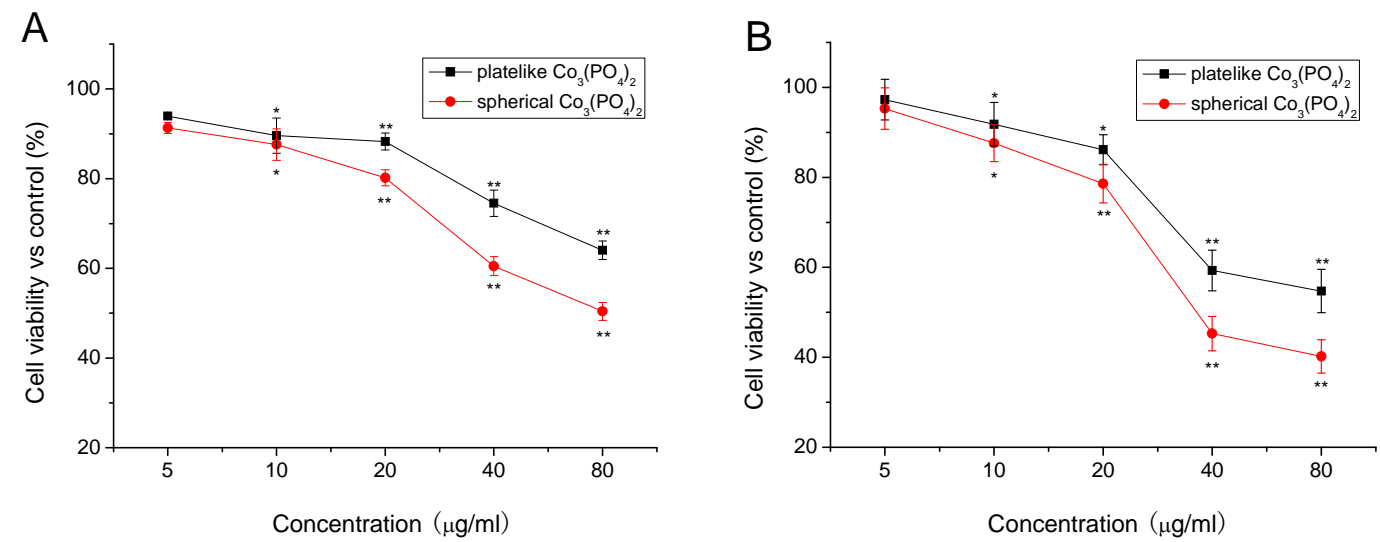

Figure 6. Effects of two types of $\mathrm{Co}_{3}\left(\mathrm{PO}_{4}\right)_{2}$ nanoparticles on the proliferation of A549 cells (A) 24 h; (B) 48 h. $\left({ }^{*} P<0.05, * * P<0.01\right.$ compared with the control group, $\mathrm{n}=6$ ) 
A

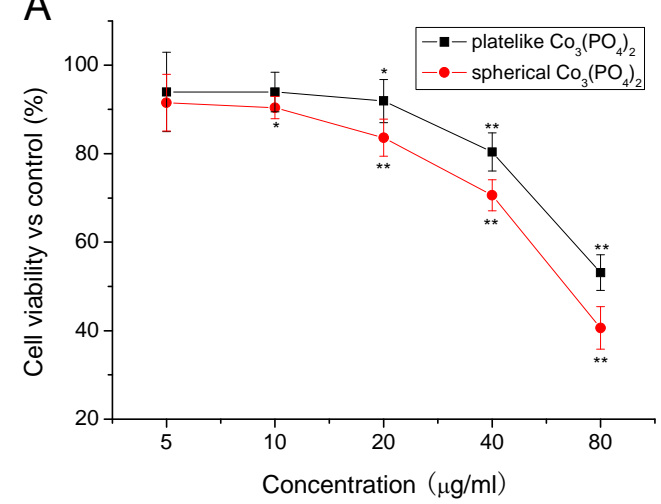

B

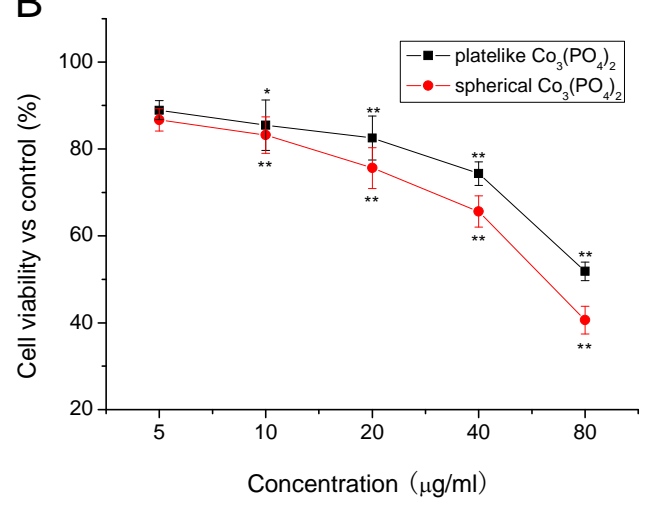

Figure 7. Effects of two types of $\mathrm{Co}_{3}\left(\mathrm{PO}_{4}\right)_{2}$ nanoparticles on the proliferation of primary mouse osteoblasts (A) 24 h; (B) 48 h. $\left({ }^{*} P<0.05, * * P<0.01\right.$ compared with the control group, $\left.\mathrm{n}=6\right)$ 